\title{
Development of banana snack using vacuum dehydration and evaluation of its nutritional, physicochemical and sensory properties
}

\author{
$\underline{\text { M.H.T.K. Chandrasiri }}^{\text {a }}$, D.N. Hettiarachchi ${ }^{\text {b*, W.A.J.P. Wijesinghe }}{ }^{\text {a }}$, V.P. Ellepola a ${ }^{\text {, }}$ \\ D.L.C.N. Hitigedara ${ }^{b}$ \\ a thilinichandrasiri22@gmail.com \\ a Department of Export Agriculture, Uva Wellassa University, Badulla 90000, Sri Lanka \\ ${ }^{\mathrm{b}}$ Food Research Unit, Department of Agriculture, Peradeniya 20400, Sri Lanka
}

\begin{abstract}
Snacks made up of Cavendish banana have dominated the world market. This study was carried out with the objective of development of banana snacks using vacuum dehydration. 80\% ripen banana slices were pretreated and dehydrated for $45^{\circ} \mathrm{C}$ and $50^{\circ} \mathrm{C}$ for one and half hours. Proximate analysis recorded $0.87 \pm 0.005 \%$ moisture, $5.2 \pm 0.01 \%$ crude fiber, $0.3 \pm 0.01 \%$ free fat, $15.4 \pm 0.01 \%$ protein, and $3.2 \pm 0.01 \%$ ash .

Total Plate Count, yeast and mold counts were less than the international limits stipulated by World Health Organization. There were no significant changes $(\mathrm{P}>0.05)$ in any sensory attribute throughout the storage of two months. There was a significant reduction in total phenolic content determined by Folin-Ciocalteau method and $\mathrm{IC}_{50}$ value determined from the DPPH radical scavenging assay. Banana Snacks developed with no usage of artificial preservatives can be stored until two months without nutritional quality deterioration.
\end{abstract}

Published by IJRP.ORG. Selection and/or peer-review under responsibility of International Journal of Research Publications (IJRP.ORG)

Keywords: Banana; Proximate analysis; Sensory evaluation; Snacks; Vacuum dehydration

\section{Introduction}

Banana (Musa acuminata) is one of the abundant cultivated varieties in Sri Lanka (Ranasinghe L., Jayawardena B. and Abeywickrama K., 2005). Although it has high nutritional value (vitamin B6, soluble fiber, resistant starch, moderate amounts of vitamins $\mathrm{C}$ which have high antioxidant activity and potassium) which cannot gain easily from any other fruit or vegetable it's post-harvest loss is nearly $30 \%$, due to less (2\%) processing of banana ( Arah et al., 2016). As they are low in fat, cholesterol and salt, a great potential exist for Banana value added products due to its limited preservation methods and its proven health benefits (Forsyth W., 1980). The soluble fiber; pectin has the tendency to slow down digestion and keep you feeling full for a longer time (Spiller G.A., 1987). Different drying techniques have been used in reducing the moisture content of fruits and to enhance quality. Pre-treatment will also stop the metabolism of cut tissue either by killing cell or by injuring enzymatic routes (Lewicki P.P. and Wickzkowska, J., 2006).In conventional drying hot/heated air is passed over the product being dried to effect drying. Some of the reasons for wide popularity of the snacks are their ready to eat nature, affordable cost, availability in different tastes and longer shelf life (Julie C., et al., 2016). 
This study was focused on development of banana snacks using vacuum dehydration and Evaluation of its' Nutritional, Physicochemical, Sensory properties. Less people are aware of the dehydration methods and the uses of them for dehydration of banana to reduce postharvest loss (Robinson J.C., 1996). Less research exposure towards development of value added products of banana, to compare the different drying methods regards to their nutritional analysis (Kowalska, J.,Kowlaska H., Marzec, A.et al 2018). Society already consume banana snacks which are deep fried, baked or harmful preservative added snacks which leads to noncommunicable diseases like cholesterol, Cardio Vascular Diseases, Cancers. Developed banana snacks without any artificial preservatives will be the best alternative for deep fried, baked snacks with artificial preservatives which is a key dietary contributor to coronary heart disease and perhaps some types of cancers. The low glycemic index of bananas is explained by their high content of resistant starch and fiber, which mitigates the blood sugar rise after a meal. A high proportion of starch in unripe bananas is resistant starch, which, as the name suggests, is resistant to digestion and is therefore a type of fiber. Resistant starch passes down to the large intestine where it is fermented by bacteria in a process that forms butyrate, a short-chain fatty acid that appears to have beneficial effects on intestinal health. Bananas are nutritious and even carry the title of the first "super food," endorsed by the American Medical Association in the early 20th century as a health food for children and a treatment for celiac disease according to Journal of American Medical Association.

Fruits need to be treated with certain pre-treatments before the drying to prevent browning and darkening of the fruit and minimize the adverse changes that occur during drying and subsequent storage. Pre-treatment will also stop the metabolism of cut tissue either by killing cell or by injuring enzymatic routes (Doymaz, and Altıner, 2012).

High shelf life coupled with adequate processing facilities results in heavy revenue to the country by exportation. Development of snacks using most abundant banana varieties in Sri Lanka with appropriate dehydration techniques to produce healthier, shelf stable and convenience are the prime requirements that achieved by this study for the present competitive markets. Also, the organoleptic properties, almost the nutritional value is preserved and concentrated according to (Ponting N.W.1993). Microbial properties and the sensory quality attributes of the developed final product was tested in order to evaluate the shelf life. The sensory quality is a combination of different sense of perception coming into play choosing and eating a food. The physicochemical and phytochemical properties were analyzed during storage. Proximate analysis was carried out for final product.

\section{Materials and methods}

This research was conducted at the Food Research Unit, Department of Agriculture, Peradeniya, Sri Lanka from August, 2018 to November, 2018.

\subsection{Ingredient collection and snack preparation}

Eighty percent ripen and more yellowish than green fresh banana (variety Embul) were purchased from a commercial farm. Diseased and damaged fruits were discarded to minimize biological variability. Fruits were well cleaned with clean water to remove dirt, dust and pesticide residues (if any). The stem scars were removed from the fruits. Physical Parameters of fresh banana like fruit weight, maximum and minimum diameter of fruit with peel, length, skin thickness, puncture operation was recorded prior to snack preparation. Cleaned bananas were Peeled off and sliced crosswise with $7 \mathrm{~mm}$ uniform thickness and sliced bananas were dipped in $0.3 \%$ citric acid solution for 30 seconds (Doymaz, and Kocayigit, 2012). Slices were steam blanched for 1 minute to avoid enzymatic browning, to reduce development of undesirable off flavours, off colors. Processed banana was allowed to dehydrate with Vacuum Dehydration $\left(45^{\circ} \mathrm{C}\right)$. Those dehydrated banana snacks were packed in High Density Polypropylene (HDPP-300 guage) $12.5 \mathrm{~cm}$ width, $20 \mathrm{~cm}$ length dimensioned pouch and stored at room temperature $\left(27-30^{\circ} \mathrm{C}\right)$. 
Moisture, total ash, crude protein, crude fiber, free fat content of the dehydrated snacks were determined in triplicates according to the standard methods of AOAC (1990).

\subsection{Storage study}

Physicochemical, phytochemical, Microbial and Sensory properties of newly developed snacks samples were evaluated at 3 phases of storage. (Just after dehydration, Storage study after 1 month, Storage study after 2 months).

\subsubsection{Microbial analysis}

Total Plate count, Yeast and mold count and enumeration of E. coli in the snacks were evaluated using the methods of SLS: 516 part 1(1991).

\subsubsection{Total plate count}

Sterilization was done to destroy or remove all unwanted living organisms. All the glassware (Petri dish, test tubes and pipettes) were thoroughly washed and sterilized in an oven at $180^{\circ} \mathrm{C}$ for one hour. After sterilization they allowed to cool slowly.

$28 \mathrm{~g}$ nutrient agar powder was added to one litre of distilled water. It was stirred in magnetic stirrer to dissolve the content. It was boiled with agitation to completely dissolve in ingredients. Then it was sterilized in the autoclave at $121^{\circ} \mathrm{C}$ for $15-20$ minutes at 15 PSI. The medium was cooled to $45^{\circ} \mathrm{C}$ and poured into sterilized petri dishes.

Lamina air flow and hands were sterilized chemically by using $70 \%$ ethanol. Then $1 \mathrm{~g}$ of sample was put into test tube and $9 \mathrm{ml}$ of sterilized distilled water was added into it by using a pipette.

The mixture was shaken by the help of shaker. After the preparation of stock solution, following dilution series were prepared, $10^{-1}, 10^{-2}$ and $10^{-3}$.

After setting the agar in the petri dishes, $1 \mathrm{ml}$ of inoculums were added into petri dishes in the lamina flow environment. It was allowed to spread the inoculums in the petri dish by shaking and immediately it was sealed by parafilm. Each plate was prepared by using above procedure. All the plates were incubated at $38^{\circ} \mathrm{C}$ for 48 hours. Colonies were counted with the help of colony counter and Total Plate Count was calculated as in Equation 1.

$$
N=\Sigma c \div[n]+(0.01 n 2) d]
$$

Where,

$\Sigma c-$ The sum of colony count on all plates

$\mathrm{n}_{1}-$ The number of plates retained in the first dilution

$\mathrm{n}_{2}$ - The number of plates retained in the second dilution

$\mathrm{d}$ - The dilution factor corresponding the first dilution 


\subsubsection{Yeast and mold count}

Sterilization was done to destroy or remove all unwanted living organisms. All the glassware (Petri dish, test tubes and pipettes) were thoroughly washed and sterilized in an oven at $180^{\circ} \mathrm{C}$ for one hour. After sterilization they allowed to cool slowly.

$18 \mathrm{~g}$ of potato dextrose agar powder was added to $500 \mathrm{ml}$ of distilled water. It was boiled with agitation to completely dissolve in ingredients. Then it was sterilized in the autoclave at $121^{\circ} \mathrm{C}$ for $15-20$ minutes at 15 PSI. The medium was cooled to $45^{\circ} \mathrm{C}$ and poured into sterilized petri dishes.

Lamina air flow and hands were sterilized chemically by using $70 \%$ ethanol. Then $1 \mathrm{~g}$ of sample was put into test tube and $9 \mathrm{ml}$ of sterilized distilled water was added into it by using pipette. The mixture was shaken by the help of shaker. After preparation stock solution following dilution series were prepared $\left(10^{-1}, 10^{2}\right.$ and $10^{-}$ 3).

After setting the agar in the petri dishes, $1 \mathrm{ml}$ of inoculums were added into petri dishes in the lamina flow environment. It was allowed to spread the inoculums in the petri dish by shaking and immediately it was sealed by parafilm. Each plate was prepared by using above procedure. All the plates were incubated at $38^{\circ} \mathrm{C}$ for 48 hours. Colonies were counted by the help of colony counter and Yeast and mold count was calculated as in Equation 2.

$\left.N=2 c \div[n]+\left(0.01 n_{2}\right) d\right]$

Where,

$\Sigma c-$ The sum of colony count on all plates

$\mathrm{n}_{1}-$ The number of plates retained in the first dilution

$\mathrm{n}_{2}$ - The number of plates retained in the second dilution

$\mathrm{d}$ - The dilution factor corresponding the first dilution

\subsubsection{Enumeration of Escherichia coli}

$3.7 \mathrm{~g}$ of Escherichia coli (E. coli) broth powder was weighted and added into a clean $250 \mathrm{ml}$ conical flask and made up to $100 \mathrm{ml}$ with distilled water. This media was filled ( $9 \mathrm{ml}$ into each) into tubes with caps containing inverted Durham's tubes in such a way that air bubbles did not get trapped inside them. There tubes were sterilized at $121^{\circ} \mathrm{C}$ for 15 minutes using autoclave.

$1 \mathrm{ml}$ of sample was added to each above test tube using sterilized pipette. Here, the $E$. coli broth should not be disturbed. These test tubes were kept for incubation at room temperature on the laminar flow and looked for gas production.

2.3.2 Physicochemical, phytochemical analysis

2.3.2.1 $\mathrm{pH}$

One gram of powdered banana snack sample was taken into a small beaker and $7 \mathrm{ml}$ of distilled water was added to prepare the solution into beakers. The meter was calibrated using buffers in $\mathrm{pH} 4,7$ and 9 . The electrode probe of the $\mathrm{pH}$ meter was rinsed with distilled water and $\mathrm{pH}$ was measured by dipping the electrode. Three replicates were recorded for each treatment (AOAC 981.12, 1996). 


\subsubsection{Moisture content}

The empty dishes and lids were dried in the oven at $105^{\circ} \mathrm{C}$ for 3 hours and they were transferred to the desiccator for cooling. The empty dishes were weighed and 5 grams of samples were weighed to the dish (Weight of wet sample). Dishes were placed with the samples in the oven and it was dried for 3 hours at $105^{\circ} \mathrm{C}$. After drying the dishes with partially covered lids, were transferred in to desiccator for cooling. The dishes and their lids were reweighed (Weight of dry sample). The process of drying, cooling, weighing were repeated at 30 minutes interval until constant weight was achieved. The lowest weight was recorded, Moisture content was determined to the below mentioned standard equation 3 (AOAC 934.01, 1996).

$$
\% \text { Moisture }\left(\frac{W}{W}\right)=\frac{\text { weight of wet sample-weight of dry sample }}{\text { weight of wet sample }} 100
$$

\subsubsection{Firmness}

For the dehydrated snacks samples, penetrometer was held at the centre of the slice and at 2 points in the diameter. Then, it was pressed until just before the penetration could happen due to the pressure. Three replicates were recorded.

Proper unit for firmness may be used because it will be inappropriate to use pressure, while pound force or kg-force be preferred in industry. Newton is the required unit for scientific writing. The conversion factors are mentioned as follows in the equation 4 and 5 .

Pound force $(\mathrm{b} b \mathrm{f}) \mathrm{x} .448=$ Newton $(\mathrm{N})$

Kilogranforce $(\mathrm{kgf}) \times 9.807=\mathrm{New}$ ton (N)

\subsubsection{Ascorbic acid content}

For standardization purpose, $5 \mathrm{ml}$ of standard ascorbic acid solution was dissolved in $5 \mathrm{ml}$ of $3 \%$ metaphosphoric acid solution and titrated against 2, 6-dichlorophenol indophenol dye until the faint pink color persisted for 15 seconds. Determined the dye factor by the equation (Dye factor $=0.5 /$ titre).

Ascorbic acid was determined by oxidizing it in acidic medium using 2, 6-dichlorophenol indophenol dye. The dye 2, 6-dichlorophenol indophenol is a blue dye in neutral or alkaline solution and colourless in the leuco reduced form. The blue dye when present in excess (on completion of the oxidation of ascorbic acid) turns pink in acidic medium and this change in color is conveniently utilized as a self-indicator to mark the end point of the titration. Ascorbic acid is sensitive to oxidative deterioration. Therefore, it is extracted from the juice in acidic medium using 3\% metaphosphoric acid solution.

One gram of powdered snack sample was taken into a small beaker and $7 \mathrm{ml}$ of distilled water was added to dissolve the powder and prepared the solution. Taken $2 \mathrm{~g}$ from each prepared powder solutions was added to $20 \mathrm{ml}$ of metaphosphoric acid and mixed well. Three replicates were taken to conical flasks ( $5 \mathrm{ml}$ each) and titrated against 2, 6-dichlorophenol indophenol dye until the faint pink color persisted for 15 seconds. Three replicates were taken to conical flasks ( $5 \mathrm{ml}$ each) and titrated against 2, 6 dichlorophenol indophenol dye until the faint pink color persisted for 15 seconds according to Source: 2, 6 dichlorophenol-indophenol visual titration method and with the use of equation 6 Ascorbic acid content was calculated (AOAC 967.21, 2000).

mg of ascorbic acid per $100 \mathrm{~g}=(T \times D \times V \times 100) \div(\mathrm{A} \times W)$ 
Where,

T - Titre

$\mathrm{D}$ - Dye factor

$\mathrm{V}$ - Volume made up

A - Aliquot of extract taken for estimation

W - Weight of sample taken for estimation

\subsubsection{Total phenolic content}

One gram of powdered sample was taken into a small beaker and added $7 \mathrm{ml}$ of distilled water to dissolve the powder and prepared the solution. Taken $1.2 \mathrm{~g}$ each from the prepared powder solutions. Each sample was mixed with $10 \mathrm{ml}$ of $80 \%$ methanol. The solutions were put into screw cap tubes and centrifuged the tubes at $11,000 \mathrm{rpm}$ for 25 minutes.

$2.5 \mathrm{ml}$ of distilled water and $0.15 \mathrm{ml}$ of $0.25 \mathrm{~N}$ fresh Folin- Ciocalteau solution were added with $0.1 \mathrm{ml}$ of prepared sample extracts. Here, $0.25 \mathrm{~N}$ Folin ciocalteau solution was prepared by mixing $1 \mathrm{ml}$ of fresh folin ciocalteau with $7 \mathrm{ml}$ of distilled water. Incubated the samples for 3 minutes. $300 \mu \mathrm{l}$ of $1 \mathrm{~N}$ Sodium carbonate solution was added. 1N Sodium carbonate was prepared by mixing $1.069 \mathrm{~g}$ with $10 \mathrm{ml}$ of distilled water. Samples were incubated in dark conditions at $23^{\circ} \mathrm{C}$ for 2 hours. Absorbance of resulting blue colour solution was determined at $765 \mathrm{~nm}$ using visible spectrophotometer.

A standard curve was prepared using same procedure with a series of gallic acid at $0,20,40,60,80,100$, $120,140 \mathrm{mgl}^{-1}$. With the help of the calibration curve, the phenolic concentration of extracts was determined and for the calculation equation 7 was used (Singleton 1991).

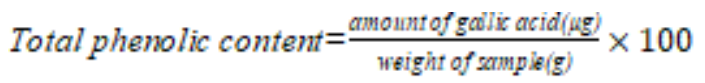

\subsubsection{Antioxidant activity}

One gram of each powder sample was taken into a small beaker and $7 \mathrm{ml}$ was added in to distilled water and solution was prepared. Taken $1.2 \mathrm{~g}$ each from the prepared powder solutions and it was mixed with $20 \mathrm{ml}$ of $80 \%$ methanol. The solutions were put into screw cap tubes and centrifuged the tubes at $11,000 \mathrm{rpm}$ for 10 minutes.

Three screw cap tube sets were taken and filled $1 \mathrm{ml}$ of $80 \%$ methanol to each tube. $20 \mu \mathrm{l}$ of the samples was put into first tube set. $40 \mu \mathrm{l}$ of the samples was put into second tube set and $80 \mu \mathrm{l}$ of the samples was put into third tube set. All the tubes were vortexed using a vortex mixer for 2 minutes. $0.5 \mathrm{ml}$ sample was taken into another tube and $2.5 \mathrm{ml}$ of DPPH solution was added to each tube. The test tubes were kept in a dark room for 20 minutes and absorbance was determined at $517 \mathrm{~nm}$ using visible spectrophotometer and radical scavenging activity was calculated based on the equation 8 as follows (Boonprakob and Thaipong, 2006).

Radical scavenging activity $(\%)=[(B-S) \div B] \times 100$

Where,

B - DPPH blank value

$\mathrm{S}$ - Sample value 
Developed snack samples were tested for color, aroma, taste, mouth-feel, texture, overall acceptability by using 25 trained sensory panelists and 9-point hedonic scale.

\subsection{Statistical analysis}

Statistical data analysis was done with Minitab 16 Statistical software. Sensory evaluation data were analyzed with Kruskal Wallis non parametric statistical method which regards to color, aroma, taste, mouth feel, texture, overall acceptability. Physicochemical properties, phytochemical properties and proximate analysis of the final product was analyzed with one-way ANOVA at 95\% significance level and Tukey's test $(\mathrm{p} \leq 0.05)$ to for mean comparison.

\section{Results and discussion}

3.1 Proximate analysis

Table 1: Proximate analysis of snack sample

\begin{tabular}{ccc}
\hline Proximate constituent & Embul Banana snacks & Fresh Embul banana \\
\hline Moisture \% & $0.87 \pm 0.005$ & $74.91 \pm 0.005$ \\
Crude fiber \% & $5.20 \pm 0.01$ & $2.6 \pm 0.00$ \\
Fat \% & $0.30 \pm 0.01$ & $0.33 \pm 0.00$ \\
Protein \% & $15.4 \pm 0.01$ & $1.09 \pm 0.00$ \\
Carbohydrate\% & $74.89 \pm 0.13$ & $22.84 \pm 0.00$ \\
\hline
\end{tabular}

Values are means of triplicates \pm Standard error

As the data shown in the table 1, it confirms that processing of Embul banana into dehydrated banana snacks is effective which regards to nutritional value as it has concentrated the nutritional constituents according to sources of USDA National Nutrient Database, 2018. There is no any significant difference in free fat content of the fresh banana and dehydrated banana snack samples.

\subsection{Microbiological Quality}

Microbial count of the dehydrated foods depends on handling quality of utensils and personal hygiene of food handlers during processing. There was no any mean plate count observed for banana snack samples during storage of 2 months. Thus far, bacteria had not grew in these snacks, as bacteria find conditions of low $\mathrm{pH}$ of the dehydrated snacks, low moisture content of snacks or high temperature during dehydration unfavorable. With the time there is a slight increment of mean counts in yeast and mold. Still those are less than the international stipulated standard limits by WHO $\left(<10^{1} \mathrm{CFUg}^{-1}\right)$ for dehydrated fruits. There is no any indicator organisms of food contamination like E. coli. Therefore, final product is acceptable for the human consumption until 2 months of storage. 
3.3 Physicochemical and phytochemical results of final product during storage

Table 2: Changes in phytochemical properties of snack during storage

\begin{tabular}{lcccc}
\hline \multicolumn{1}{c}{ Storage time } & $\begin{array}{c}\text { Ascorbic acid } \\
\text { content } \\
(\mathrm{mg} / 100 \mathrm{~g})\end{array}$ & $\begin{array}{c}\text { Total Phenolic content } \\
(\mathrm{mg} \mathrm{GAE} \mathrm{100} \mathrm{g-1})\end{array}$ & $\begin{array}{c}\text { Mean Antioxidant } \\
\text { activity (IC50) } \\
(\mathrm{mg} \text { mL-1 })\end{array}$ & $\mathrm{pH}$ \\
\hline Initial (0) & $10.79^{\mathrm{a}} \pm 0.005$ & $281.86^{\mathrm{a}} \pm 1.18$ & $234.06^{\mathrm{c}} \pm 1.03$ & $5.12^{\mathrm{a}} \pm 0.005$ \\
$1^{\text {st }}$ month (30) & $10.75^{\mathrm{a}} \pm 0.05$ & $260.10^{\mathrm{b}} \pm 0.1$ & $533.30^{\mathrm{b}} \pm 3.24$ & $4.28^{\mathrm{b}} \pm 0.015$ \\
$2^{\text {nd }}$ month (60) & $10.75^{\mathrm{a}} \pm 0.17$ & $224.70^{\mathrm{c}} \pm 0.29$ & $934.04^{\mathrm{a}} \pm 2.22$ & $4.17^{\mathrm{c}} \pm 0.02$ \\
\hline
\end{tabular}

Values are means of triplicates \pm Standard error

Means with the same letters in same column are not significantly different from each other

Ascorbic acid is highly sensitive to light, heat, oxygen which accelerates oxidation of ascorbic acid. But here, mean ascorbic acid content did not significantly changed with the time for snacks as shown in the table 2 . It's because of the lower temperatures during vacuum dehydration which ensures that there is no prolong heating. So low temperatures arrest oxidation of ascorbic acid (Apei, L. and Hwa, L., 2014). As shown in the table 2. the total phenolic compounds significantly reduced with the time due to oxidation with the polyphenolic oxidase enzyme which tally with the antioxidant activity results. Oxidation of total polyphenolic compounds leads to significant reduction in antioxidant activity.

According to table no. 2, significant reduction in $\mathrm{pH}$ is due to the reaction of basic amines to form compounds of lower basicity (Beck, R. A., \& Zapsalis, C., 1985). There is no any significant difference in mean firmness as its firmness values are $4.27^{\mathrm{a}} \pm 0.01,4.28^{\mathrm{a}} \pm 0.01,4.29^{\mathrm{a}} \pm 0.005$. As shown in the figure 1 , there is no any significant change in firmness, the crispiness of snacks won't change.

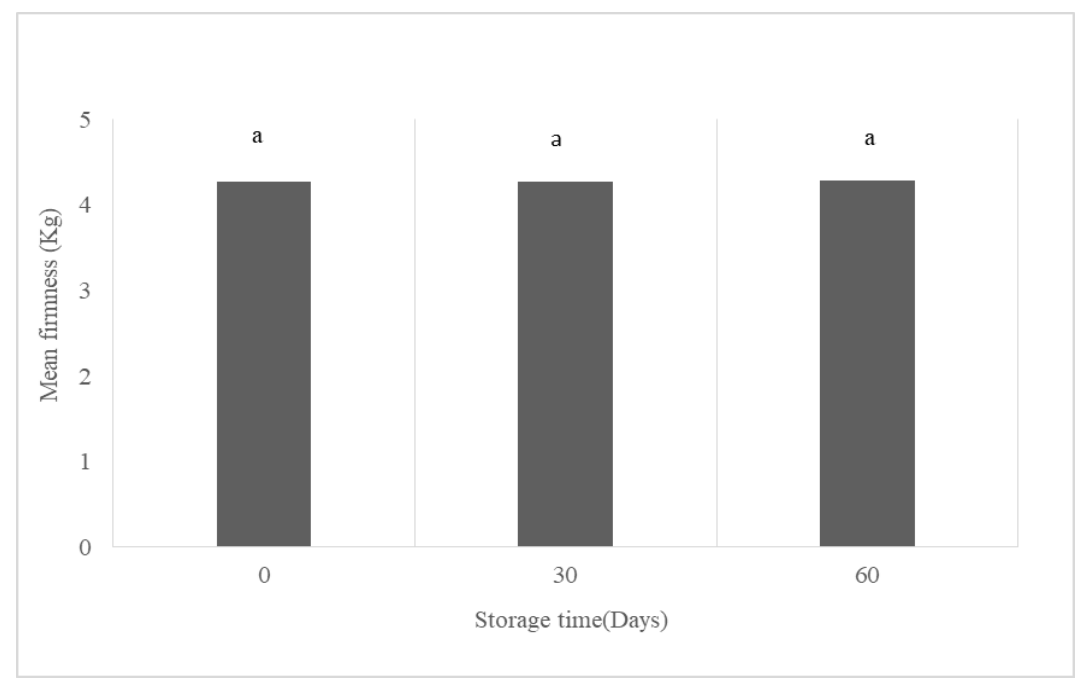

Figure 1. Changes of mean firmness during storage. The same letters $(a, a, a)$ denote that there is no any significant change in the mean firmness during the storage time period of just after dehydration (0), after 1 month (30), after 2 months(60). 
Figure 2. Changes of mean moisture content during storage, The different letters $(\mathrm{c}, \mathrm{b}, \mathrm{a})$ denote that the moisture content of the snacks has being increasing during the storage of $0,30,60$ days.

Due to hygroscopic nature of dehydrated snacks which leads to absorption of water from atmosphere, moisture content also significantly increases with the time as in the figure 2. Although 300 guage HDPP bags were used, based on the above result it is recommended to have more detailed packing like vacuum packing to minimize the rise of moisture content.

\subsection{Sensory evaluation}

Table 3: Estimated median values of sensory evaluation for shelf life studies of snacks

\begin{tabular}{ccccc}
\hline \multirow{2}{*}{ Sensory attribute } & \multicolumn{3}{c}{ median values } \\
\cline { 2 - 4 } Color & Initial & 1 month & 2 months & P value \\
Aroma & 9.00 & 9.00 & 9.00 & 0.368 \\
Taste & 6.00 & 6.00 & 6.00 & 0.268 \\
Mouth feel & 9.00 & 8.00 & 8.00 & 0.764 \\
Texture & 8.00 & 8.00 & 8.00 & 0.519 \\
Overall Acceptability & 8.00 & 8.00 & 8.00 & 0.301 \\
\hline
\end{tabular}

All the data are given as estimated median values.

According to table no. 3 as p values for each and every sensory attributes are greater than 0.05 , there is no any significant change of attributes with the storage time which means that consumer acceptability won't change over time which ensures consumer demand depend on sensory evaluation principles.

Below illustrated figure 3 with the web diagram of the sensory data for the shelf life evaluation showed that there is no any significant difference in color, aroma, taste, mouth feel, texture, overall acceptability of snacks during storage of 2 months. 


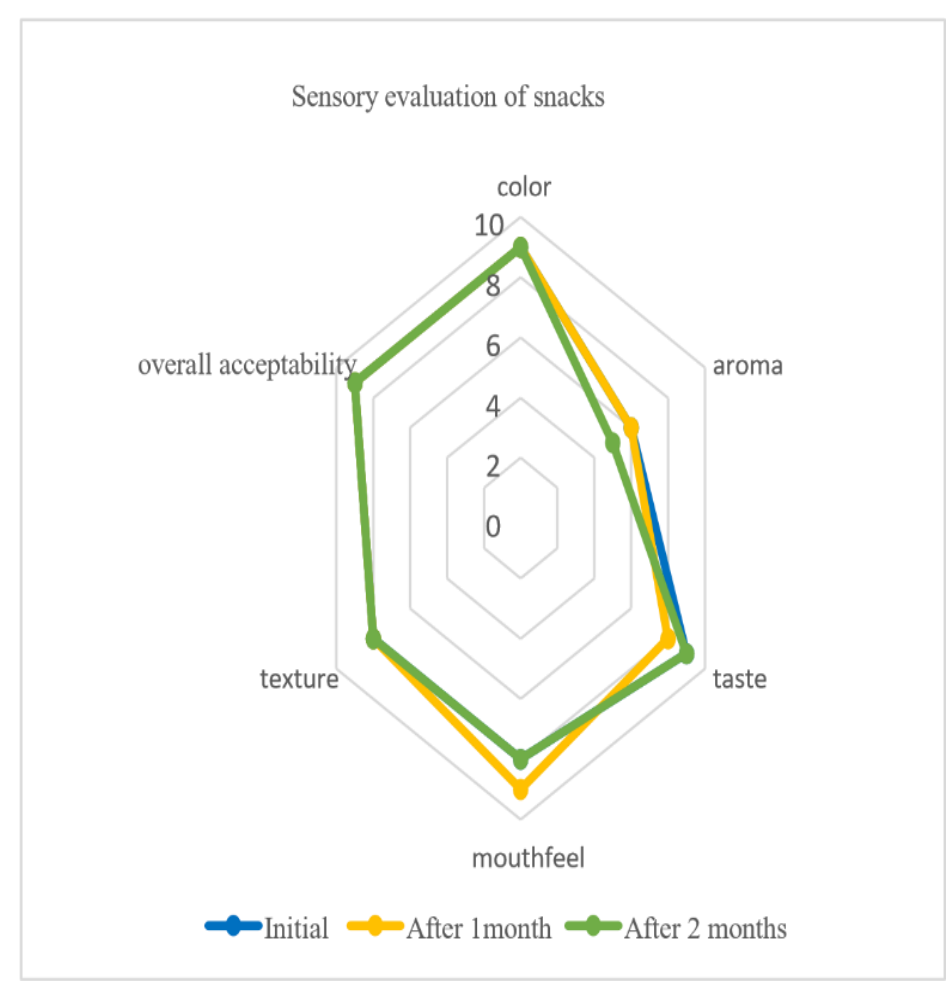

Figure 3: web diagram for sensory attribute evaluation of vacuum dehydrated embul banana snacks

\section{Conclusion}

Embul Banana (Musa acuminata AAB) is one of the nutritious fruit available throughout the island. This research was done to utilize the excess production of embul banana in Sri Lanka and to enhance the shelf life by producing a dehydrated snack. Although there is a slight increment of mean counts in yeast and molds of the snack, those are less than the international stipulated standard limits by WHO $\left(<10^{1} \mathrm{CFUg}^{-1}\right)$ for dehydrated fruits. Further there is no any indicator organisms of food contamination like E. coli. Therefore, final product is acceptable for the human consumption until 2 months of storage. Developed snack will be a best alternative for snacks or food products which are fried or preserved artificially $(0.30 \pm 0.01 \%$ fat content, $5.20 \pm 0.01 \%$ crude fiber) based on the proximate analysis results. There is no any significant change in the sensory attributes of snacks which maintains the consumer acceptability throughout the storage of two months.

\section{Acknowledgement}

I would like to express my sincere gratitude to my internal supervisor, Dr. W. A. J. P. Wijesinghe, senior lecturer, Department of Export Agriculture, Faculty of Animal science and Export Agriculture, Uva Wellassa University for devoting his valuable time, kind supervision, advices and encouragement in completing this research project successfully and my external supervisor Ms. D.N. Hettiarachchi, Assistant Director, Food Research Unit, Department of Agriculture, Peradeniya for providing necessary guidance and assistance throughout the research period. I also wish to express my gratitude to the officials and other staff members of food research unit, Peradeniya who rendered their help during the period of this study. 


\section{References}

AOAC. Official methods of analysis of AOAC Intl.17 th ed. Method No. 963.15. The Association of Official Agricultural Chemists. Arlington, VA, USA. P. 1588 (1995).

AOAC. Official methods of analysis of AOAC Intl.17 th ed. Method No. 934.06. The Association of Official Agricultural Chemists. Washington, DC, USA, (2000).

AOAC. Official methods of analysis of AOAC Intl.17 th ed. Method No. 978.23. The Association of Official Agricultural Chemists. Washington, DC, USA, (1990).

AOAC. Official methods of analysis of AOAC Intl.17 th ed. Method No. 981.12. The Association of Official Agricultural Chemists. Washington, DC, USA, (1996).

Apei, L. and Hwa, L. (2014). Study on the Kinetics of Vitamin C Degradation in Fresh Strawberry Juices. Procedia Chemistry, [online] 9, pp.62-68. Available at: https://www.sciencedirect.com/science/article/pii/S1876619614000096 [Accessed 19 Jul. 2019].

Arah, Isaac \& Ahorbo, Gerald \& Anku, Etornam \& Kumah, Ernest \& Amaglo, Harrison. (2016). Postharvest Handling Practices and Treatment Methods for Tomato Handlers in Developing Countries: A Mini Review. Advances in Agriculture. 2016. 8 pages.

Banana Statistical compendium, Food and Agriculture Organization of the United Nations Rome, 2017

Beck, R. A., \& Zapsalis, C. (1985). "Water in foods, physical and chemical phenomena" in Food Chemistry and Nutritional Biochemistry. New York: Macmillan Publishing Company

C. Julie M Hess, Satya S. Jonnalagadda, Joanne L Slavin, What Is a Snack, Why Do We Snack, and How Can We Choose Better Snacks? A Review of the Definitions of Snacking, Motivations to Snack, Contributions to Dietary Intake, and Recommendations for Improvement, Advances in Nutrition, Volume 7, Issue 3, May 2016, Pages 466-475.

Doymaz, I., Kocayigit F. Effect of Pretreatments on drying, rehydration, and color charateristics of red pepper ('Charliston' variety). Food Sci Biotechnol 21, 1013- 1022 (2012).

Doymaz, i., Altıner, P. Effect of pretreatment solution on drying and color characteristics of seedless grapes. Food Sci Biotechnol 21, 4349 (2012).

Forsyth, W., 1980 Banana and plantains, In : S. Nagy \& P. Shaw, eds. Tropical and subtropical fruits. West port, CT: AVI, pp.258-278.

Kowalska, J., Kowalska H., Marzec, A. et al. Dried Strawberries as a high nutritional value fruit snack. Food Sci Biotechnol 27, 799-807 (2018).

Lewicki, P.P. \& Wiczkowska, J. (2006). Rehydration of apple dried by different methods. International Journal of Food Properties (in press).

Loesecke, H. W., Bananas-Chemistry, Physiology, Technology,2 nd ed. NewYork: Inter science Publishers inc. (1950).

Lawless, H. and Heymann, H. (2013). Sensory Evaluation of Food. New York, NY: Springer.

Lee, E., Yeom, H., Ha, M. et al. Development of banana peel jelly and its antioxidant and textural properties. Food Sci Biotechnol 19, 449455 (2010).

Ponting, N. W., 1993. Optimization of processing conditions for improved nutritional and flavour quality of dehydrated products. Food Technol. Aust., 45: 480-486.

Ranasinghe L., Jayawardena B. and Abeywickrama K. 2005. An integrated strategy to control post-harvest decay of Embul banana by combining essential oils with modified atmosphere packaging International Journal of Food Science \& Technology 40(1): pp 97 103. 
Singleton Vernon L. Rudolf Orthofer Rosa M.Lamuela-Raventós, Analysis of total phenols and other oxidation substrates and antioxidants by means of folin-ciocalteu reagent, Volume 299, 1999, Pages 152-178, https://doi.org/10.1016/S0076-6879(99)99017-1.

Sri Lanka Standard Institute. (1991). Methods for microbial analysis. SLS 516 part 1: 1991 Colombo.

Someya, S., Yoshiki, Y. and Okubo, K. (2002). Antioxidant compounds from banana Food Chemistry, 79(3), pp.351-354.

Spiller GA. Handbook of Dietary Fiber in Human Nutrition. 3rd ed. CRC Press, Inc., Boca Raton, FL, USA. p. 339 (1986).

Stover, R.H. and N.W. Simmonds, 1987. Banana, Tropical Agriculture Series. 3rd Edn., Longman Singapore Publisher, Singapore, pp: 373370.

Thaipong K, Boonprakob U, Crosby K Zevallos- Cisneros L, Byrne DH. Comparison of ABTS, DPPH, FRAP and ORAC assays for estimating antioxidant activity from guava fruit extracts. J. Food Compos. Anal.19: 669-675 (2006).

The Banana Again. Journal of American Medical Association. 1917;6923:1972- 1974.

USDA National Nutrient Database for Standard Reference Legacy Release, April 2018. 